\title{
Success and Survival of Re-torquing an Early Failed Dental Implant: A 2-Year Multicenter Prospective Study
}

\author{
Original \\ Article \\ Omar Soliman \\ Department of Periodontology and Oral Diagnosis, Faculty of Dentistry, South \\ Valley University, Egypt
}

\begin{abstract}
Purpose: The aim of the present study was to evaluate the clinical status and radiographic changes as parameters for the success or failure of retorquing an early failed dental implant.

Materials and Methods: Fifteen male patients with early failed single tooth dental implants of rotational mobility were selected. Retorquing was performed and plaque and gingiva. Data were recorded at the time of retorquing and 6, 12, 18 and 24 months later.

Results: Fifteen loosed implants in 15 patients were evaluated. Four implants were lost, smoking was reported by two patients. The implants that survived were followed for 12 months and showed good clinical results.

Conclusion: The attempt to retighten implants in sites where implants had early failed (rotational movement) previously results in good survival rate.
\end{abstract}

Key Words: Early implant failure, Implant loose, Re torque.

Received: 09 July 2020, Accepted: 27 October 2020.

Corresponding Author: Omar Soliman, Department of Periodontology and Oral Diagnosis, Faculty of Dentistry, South Valley University, Egypt, Tel.: +201009634358, Mobile: +201201005457, E-mail: dr.omar.soliman@outlook.de.

ISSN: 2090-097X, April 2020, Vol. 11, No. 2

\section{INTRODUCTION}

Most dental implant failures occur at early stages of peri-implant healing (Marco et al. 2004). Early implant failure is the inadequacy of the host tissue to establish osseointegration and occurring prior to or at abutment connection. Early failures often are associated with a disruption that occurs during the initial healing phase, leading to fibrous tissue formation between the fixture surface and the surrounding bone. This allow epithelial down growth to occur, which can lead to implant mobility and eventual implant failure (Yifat et al. 2009).

If an implant does not undergo osseointegration, cessation of the parameters producing primarily fibrous tissue for an additional three weeks was accompanied by tissue differentiation into bone. Excessive micromotion (in excess of $150 \mu \mathrm{m}$ ) during implant healing can induce connective tissue encapsulation, there is some evidence indicating that once the cause of instability is removed, the fibrous tissue may differentiate back into bone (Linish and Peteris 2003).

The criteria for successful osseointegration of dental implants are: lack of mobility is of prime importance as 'loosening' is the most often cited reason for implant fixture removal (Albrektsson 1986). Mobility of implants is the key sign of failure (Salah and Paul 2011). This clinically noticeable situation can be present without distinct radiographic signs of bone changes (Gröndahl and Lekholm 1997). Different kinds of mobility: horizontal, vertical and rotation mobility have been recognized (Shulman et al. 1996). The reverse torque test was proposed to discover mobile implants (Sullivan et al.1996) and the periotest device can be used for a better evaluation of horizontal mobility (Tricio et al. 1995). While rotational mobility may reflect an immature bone/implant interface, on the other hand horizontal and vertical mobility may be associated with bone loss and the presence of soft tissue capsule (Sánchez and Gay 2004).

The consequences of implant removal jeopardize the clinician's efforts to accomplish satisfactory function and aesthetics. For the patient, this usually involves further cost and additional procedures. When treatment cost and additional procedures to the patient are considered, the clinician needs information regarding the predictability of replacement of a failed implant (Yoav and Liran 2007). The purpose of the present study was to evaluate the survival and success rate of loosed dental implants (Rotational mobility) that failed during the early healing period and treated by retightening at the same location.

\section{MATERIALS AND METHODS}

\section{Inclusion Criteria:}

Patients were selected to participate whether their clinical condition met the following inclusion criteria: (i) patients with loose implant that were planned to retightened, (ii) implant failure occurring prior to or at abutment connection, (iii) implant loose is rotational 
mobility, (iv) implant retightened in the same site where the failed implant was previously anchored, (v) original and retightened fixtures done by the same operator.

\section{Exclusion Criteria:}

On the contrary, patients were excluded from this study for one or more of the following conditions: (i) systemic status that affect bone metabolism, (ii) implant failure after prosthesis delivery and (iii) active smoker subjects ( $>10$ cigarettes / day).

\section{Implant retightening procedures:}

At the time of abutment connection, the reversetorque test was proposed to discover mobile implants, the failed and loosed (rotational mobility) implant (Figures 1 and 2), retightening by retourqing to gain stability, no rotary instruments were used at this stage. The contaminated parts of each implant (implant threads protruding from bone) were treated using $10 \%$ hydrogen peroxide $\left(\mathrm{H}_{2} \mathrm{O}_{2}\right)$ on a cotton pellet for 1 min followed by rinsing with physiological saline (Kolonidis et al. 2003). Abutment connection and prosthetic delivery take place after three months.

\section{Screening Process:}

The patients included in the study were evaluated according to the following parameters using patients records: age, gender, healthy condition, general illnesses and medication, smoking habits, anatomical position of the implant, characteristics on the loosed implant (implant length, width, and surface treatment). Each patient was given a detailed description of the procedure. They were also informed that their data would be used for statistical analysis and gave their informed consent to the treatment. No ethical committee approval was sought to start up this observational study, as it was not required by national law or by ordinance of local inspective authority.

\section{Outcome Assessment:}

The follow-up examination included clinical evaluation of implant stability, function, signs of inflammation, and radiographic assessment. Data were recorded regarding the success and survival rates of these implants. Implant failure was defined according to the criteria of Albrektsson et al. 1986 and (Misch et al. 2008), implant mobility on clinical examination, persistent pain, signs of infection, presence of peri-implant radiolucency, progressive bone loss, or the implant could not be used for prosthetic rehabilitation.

\section{RESULTS}

\section{Study Population:}

An overall of 15 implants that showed early failure in 15 patients. Overall, 15 implants were retightened in 15 patients. Among them (male: 11, female: 4) displayed early implant failure and retightened the implants. The mean follow-up in the study was 12 months.
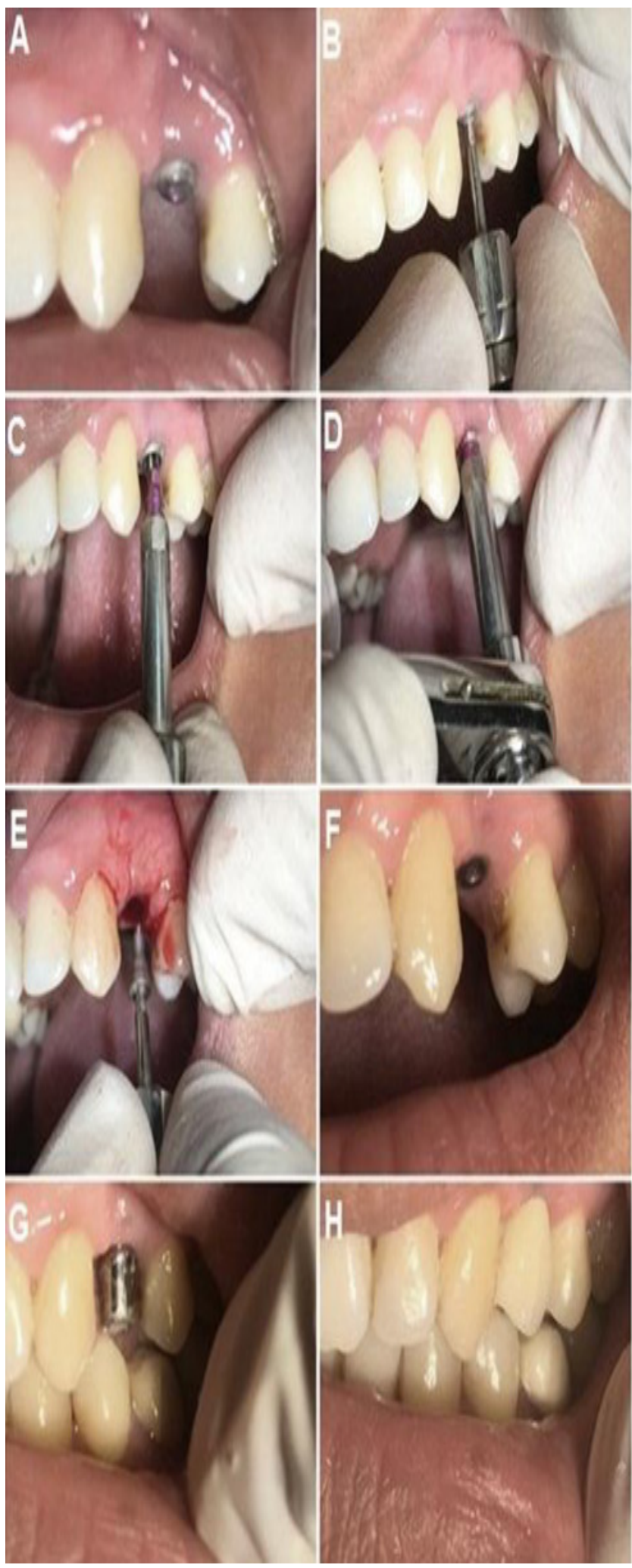

Figure 1: Photographs showing an early implant failure before abutment connection (implant loose is rotational mobility, rotate anti clock during removal of the cover screw) (A), cover screw removal (B), placement of implant mount (C), implant retorque (D), placement of cover screw (E), implant after three month healing period (F), abutment placement $(\mathrm{G})$ and crown cementation $(\mathrm{H})$. 


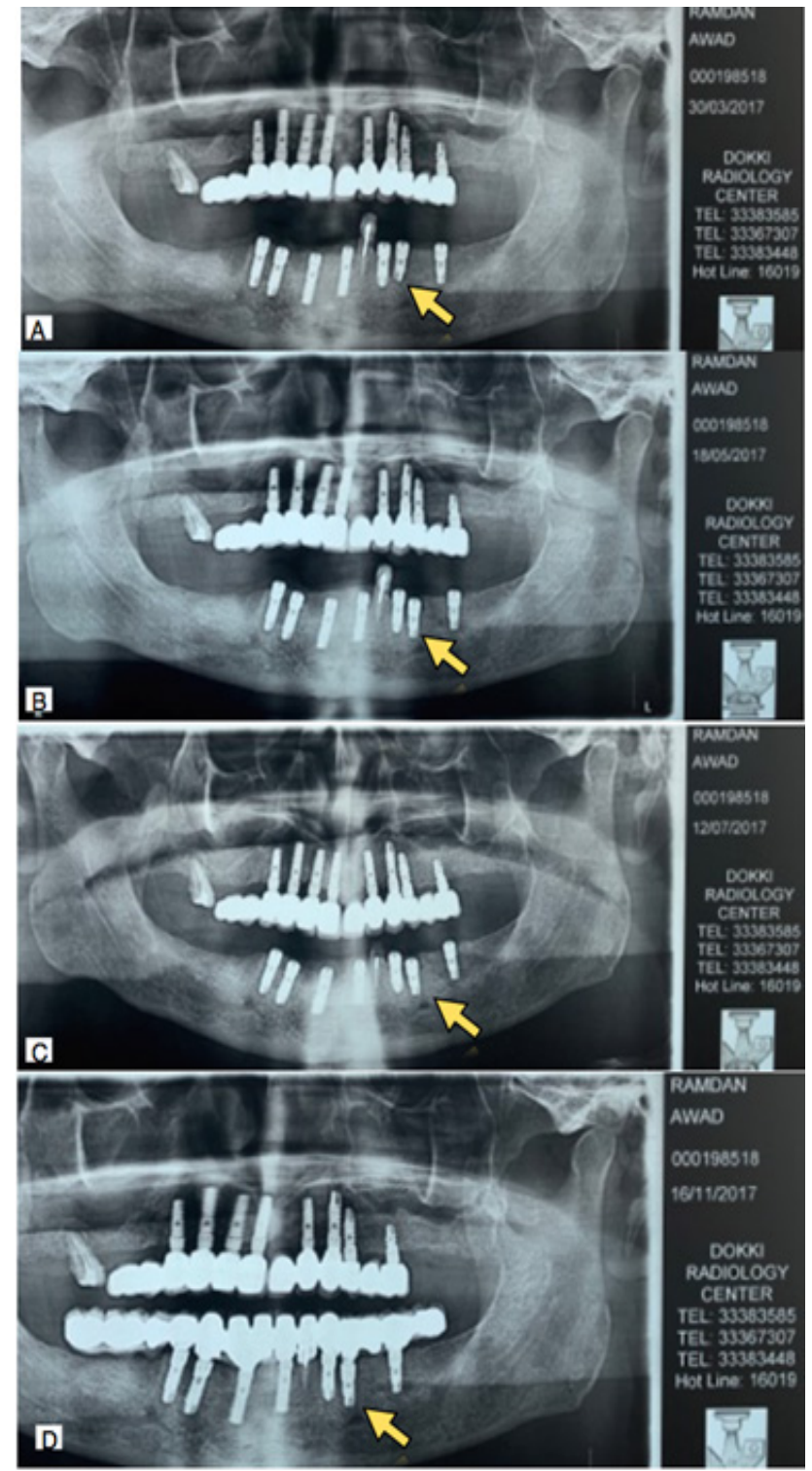

Figure 2: Photographs showing Panoramic x ray for an early implant failure before abutment connection:

(A): Panoramic $x$ ray showing implant loose.

(B): Panoramic $x$ ray showing after retoique loose implant.

(C): Panoramic $\mathrm{x}$ ray showing three months after retoique loose implant.

(D): Panoramic $\mathrm{x}$ ray showing three months after retoique loose implant.

\section{Implant characteristics:}

15 implants (Impla dental implant system (Scheutz dental group, Germany)) were retightened in all the 15 patients included. All displayed the same surface modifications (sand blasted, acid etched).

\section{Type of Prosthesis:}

14 retightened implants were restored as single unit crowns and the other 1 were restored as implants supported bridge. The average time to completion of the final prosthesis after implant placement was 3 months.

\section{Clinical Parameters of Replacement Implants:}

Four of the 15 retightened implants failed before prosthesis delivery, and two implant failures happened in smoker patients (not active smoker subjects $(>10$ cigarettes/ day)). None of these implants were lost after the first year.

\section{Implant Quality Scale:}

At the last follow-up evaluation, four of the 15 implants assessed, failed according to IQS criteria, 11 implants showed satisfactory survival, no pain or tenderness upon function was observed, showing a success rate (optimum health) of $73.3 \%$.

\section{DISCUSSION}

Dealing with failed implant present a challenging therapeutic dilemma to the clinician and patients. There is very little information in the periodontal literature on the success of surgical procedures performed to manage failed implant (Eli. et.al. 2008).

Redo of dental implants is often the prime treatment alternative for the majority of implants which have previously failed. The success of implants replacing failed ones at the exact site has been reported (Yoav and Liran. 2007).

It has been suggested that when an implant is lost, a flap should primarily cover the entrance to the site and after $9-12$ months, a new implant can be replaced at that site (Adell et al. 1981). Evian and Cutler 1995 report immediately replacing 5 failed screw type, commercially pure titanium implants with larger-diameter, hydroxyapatite- coated implants in the same sockets. They suggest that a 1 year healing period may not be necessary.

Grossmann and Levin. 2007 assessed survival and success rates of single dental implants replacing a previously failed implant at the same location, an overall survival rate of $71 \%$ was reported with a mean follow-up of $19.4 \pm 11.4$ months. there results showed that, there is a lack of sufficient evidence based data regarding failed implant replacement, they recommended that meticulous removal of granulation tissue on the failed implant site and the use of wider implants with improved surfaces could improve the outcome of re-implantation. and further research with a large cohort for a long follow-up period is warranted.

In the present study, retightening of dental implants in sites where have failed resulted in good survival rate (73.3\% first year survival). This outcome represents a good prognosis compared with implants replacement. This may due to that, retightening the implant tightened the granulation tissue surrounding the implant fixture and stimulate the fibrous tissue to differentiate back into bone. 
The interface zone between bone and implant has been the concern of recent publications. Immediately after the insertion of the implant, a layer of fibrous tissue develop around the implant and the gap between the metal surface and host bone could be appropriate for a rapid deposition of new bone, large gaps (more than $0.5 \mathrm{~mm}$ ) can reduce the quality of new peri-implant bone and delay the rate of bone filling (Marco et al. 2004) and in their study they concluded that, peri-implant marrow spaces, rich in undifferentiated cells and blood vasculature, are still detectable at the implant surface 3 months after implantation and can favour the biological turnover of the peri-implant bone.

The aim of peri-implant early healing is to fill the gap between the host bone and the implant calcified tissue. Non-integration or the loss of osseointegration are usually the consequence of poor surgical technique (overheating of the bone) (Franchi et al. 2004). Due to the surgical trauma a necrotic border zone inevitably arises immediately adjacent to the implant no matter what precautions are taken at implant insertion. This dead bone should be remodelled before implant loading is allowed. The success of the retightening the early failed implant may be due to: decreasing the gaps between the implant surface and bone. On the other hand the mechanical movement from retourqing remove the dead bone and stimulate the fibrous tissue to differentiate to bone.

Kolonidis et al. (2003) have studied the effect of surface contamination with dental plaque on the initial osseointegration of dental implants, in this study, implants were intentionally placed with some threads exposed to the oral cavity and allowed for plaque accumulation. Next these implants were explanted, their surfaces were cleaned and then reimplanted in freshly prepared implant sites. New bone formation and good bone- to-implant contact (BIC) were achieved on the portion of implant surface that was previously exposed and contaminated, thus suggesting that implants' surface contamination might not be such a major factor for failure as previously thought.

Clinicians should remember that, once an implant has failed, retourqing of that implant is subjected to at least all the initial factors that led to the failure. From the limited information that is available, it appears that redo procedures have a lower success rate than first time operations (Davierwala et al. 2006). Several patient related and site related factors might account for this phenomenon of reduced predictability of surgical procedures in these redo operations.

\section{Clinical Relevance:}

Scientific rationale for the study: Success rates for dental implants are high. Nevertheless, failures that mandate immediate implant removal occur. The consequences of implant removal jeopardize the clinician's efforts to accomplish satisfactory function and esthetics. For the patient, this usually involves further cost and additional procedures.
Principal findings: The present clinical trial aim to describe new methods and treatment modalities to deal with early dental implant failure. The main topics for discussion include identifying the failing implant and implants re torquing at the exact site.

Practical implications: The use of re torquing technique for loose implant (rotational mobility) result in good implant survival and success. Caution is required in terms of case selection.

\section{CONCLUSION}

Within the limitations of the present study, the results show that retourqing the early implant failure is a good treatment option for managing this type of implant complication.

\section{CONFLICT OF INTEREST}

The authors declare no conflict of interest.

\section{REFERENCES}

1. Abdul Hameed Droubi. Implant failure: Etiology and complications. Med Oral Patol Oral Cir Bucal. 2011 Jan 1; 16 (1): e42 - 4.

2. Adell R, Lekholm U, Rockler B, Bränemark P-I. A 15-year study of osseointegrated implants in the treatment of the edentulous jaw. Int J Oral Surg. 1981; 10: 387 - 416.

3. Adell R, Lekholm U, Rockler B, Bra nemark P-I. A 15-year study of osseointegrated implants in the treatment of the edentulous jaw. Int J Oral Surg; 10: 387 - 416. 1981.

4. Albrektsson T, Zarb G, Worthington P, Eriksson AR: The long-term efficacy of currently used dental im- plants: A review and proposed criteria of success. Int $\mathrm{J}$ Oral Maxillofac Implants 1986; 1: $11-25$.

5. Alsaadi G, Quirynen M, van Steenberghe D: The importance of implant surface characteristics in the replacement of failed implants. Int J Oral Maxillofac Implants; 21: 270 - 274. 2006.

6. Alsaadi, G., Quirynen, M. and van Steenberghe, D. (2006) The importance of implant surface characteristics in the replacement of failed implants. The International Journal of Oral and Maxillofacial Implants 21: 270 - 274. Aspenberg P, Herbertsson P. Periprosthetic bone resorption. J Bone Joint Surg 1996; 78-B: 641 - 646. 
7. Aspenberg $\mathrm{P}$, Goodman $\mathrm{S}$, Larsen $\mathrm{S}$, et al. Intermittent micromotion inhibits bone ingrowth. Titanium implants in rabbits. Acta Orthop Scand 1992; 63: 141-

8. Buser, D., Mericske-Stern, R., Bernard, J.P., Beh- neke, A., Behneke, N., Hirt, H.P., Belser, U.C. and Lang, N.P: Long-term evaluation of non- submerged ITI implants. Part 1: 8-year life table analysis of a prospective multi-centre study with 2359 implants. Clinical Oral Implants Research 8: 161 - 172. (1997).

9. Brocard, D., Barthet, P., Baysse, E., Duffort, J.F., Eller, P., Justumus, P., Marin, P., Oscaby, F., Simonet, T., Benque, E. and Brunel, G: A multicenter report on 1,022 consecutively placed ITI implants: a 7-year longitudinal study. The International Journal of Oral and Maxillofacial Implants 15: 691-700. (2000).

10. Brunski JB, Moccia AFJ, Pollack SR, et al. The influence of functional use of endosseous dental implants on the tissue-implant interface. I. Histological aspects. J Dent Res 1979; 58: 1953 - 69.

11. Brunski JB. Influence of biomechanical factors at the bone-biomaterial interface. In: Davies J.E, editor. The bone-biomaterial interface. Toronto: University of Toronto Press; 1991. p. 391 - 405.

12. Chrcanovic B, T. Albrektsson and A. Wennerberg: Reasons for failures of oral implants. Journal of Oral Rehabilitation 2014 41; 443 - 476.

13. Davierwala, P.M., Borger, M.A., David, T.E., Rao, V., Maganti, M. and Yau,: T.M.Reoperation is not an independent predictor of mortality during aortic valve surgery. The Journal of Thoracic and Cardiovascular Surgery 121: 329 - 335. 2006.

14. Evian CI, Cutler SA. Direct replacement of failed CP titanium implants with larger-diameter, HAcoated Ti-6Al-4V implants: report of five cases. Int J Oral Maxillofac Implants. 1995; 10: 736 - 43.

15. Franchi M, Orsini E, Trirè A, Quaranta M, Martini D, Piccari G, Ruggeri A, Ottani V: Osteogenesis and Morphology of the Peri-Implant Bone Facing Dental Implants. TheScientificWorldJOURNAL 4, $1083-1095.2004$.

16. Fristad, I., Molven, O. and Halse, A: Nonsurgically retreated root filled teeth-radiographic findings after $20-27$ years. International Endodontic Journal 37: 12 - 18. (2004).
17. Grossmann Y, Levin L. Success and survival of single dental implants placed in sites of previously failed implants. J Periodontol. 2007; 78 (9): 1670 - 4.

18. Glavas P, Moses MS. Stage I indexing to replace a failed implant in an edentulous arch: a clinical report. J Prosthet Dent. 2003; 89: 533 - 5.

19. Giovane Gomes, Mônica Misawa, Carolina Fernandes, Claudio Pannuti, Luciana Sariva. Guy Huynh, Cristina Villar: A systematic review and meta-analysis of the survival rate of implants placed in previously failed sites. Braz. Oral Res. 2018; 32: e27.

20. Hadi SA, Ashfaq N, Bey A, Khan S: Biological factors responsible for failure of osseointegration in oral implants (2011): Biology and Medicine, 3 (2) Special Issue: 164 - 170.

21. Kolonidis, S.G., Renvert, S., Hammerle, C.H., Lang, N.P., Harris, D. and Claffey, N. (2003) Osseointegration on implant surfaces previously contaminated with plaque. An experimental study in the dog. Clinical Oral Implants Research 14: 373 - 380 .

22. Liran Levin: Dealing with dental implant failures. J Appl Oral Sci. 2008; 16 (3):171 - 5.

23. Levin, L., Grossmann, Y. and Sadet, P: A retrospective evaluation of 1,381 implant-supported single-tooth restorations. Journal of Periodontology 77: 2080 - 2083. (2006).

24. Linish Vidyasagar, Peteris Apse: Biological Response to Dental Implant Loading / Overloading. Implant Overloading: Empiricism or Science? Stomatologija, Baltic Dental and Maxillofacial Journal, 5: 83 - 89, 2003.

25. Machtei E., Dan Mahler, Orit Oettinger-Barak, Otman Zuabiand Jacob Horwitz: Dental implants placed in previously failed sites: survival rate and factors affecting the outcome. Clin. Oral Impl. Res. 19, 2008; $259-264$.

26. Marco Franchi, Ester Orsini, Alessandra Trirè, Marilisa Quaranta, Desirée Martini, Gabriella Giuliani Piccari, Alessandro Ruggeri and Vittoria Ottani: Osteogenesis and Morphology of the Peri-Implant Bone Facing Dental Implants. The Scientific World Journal (2004) 4, 1083 - 1095.

27. Miyamoto, I., Tsuboi, Y., Wada, E., Suwa, H. and Iizuka, T. (2005) Influence of cortical 
bone thickness and implant length on implant stability at the time of surgery - clinical, prospective, biomechanical, and imaging study. Bone 37: $776-780$.

28. Ostman, P.O., Hellman, M., Wendelhag, I. and Sennerby, L: Resonance frequency analysis measurements of implants at placement surgery. The International Journal of Prosthodontics 19: $77-83.2006$.

29. Tal, H., Artzi, Z., Moses, O., Nemcovsky, C.E. and Kozlovsky, A: Spontaneous early exposure of submerged endosseous implants resulting in crestal bone loss: a clinical evaluation between stage I and stage II surgery. The International Journal of Oral and Maxillofacial Implants 16: $514-521.2001$.

30. Yoav Grossmann and Liran Levin: Success and Survival of Single Dental Implants Placed in Sites of Previously Failed Implants. J Periodontol, September 2007 Volume 78, Number 9.

31. Uhthoff HK, Germain JP. The reversal of tissue differentiation around screws. Clin Orthop 1977; 123: 248 - 52.

32. Soballe K, Hansen ES, Rasmussen B, et al. Tissue ingrowth into titanium and hydroxyapatite coated implants during stable and unstable mechanical conditions. J Orthop Res 1992; 10: 285 - 289.

33. Soballe K, Hansen S, Brockstedt-Rasmussen $\mathrm{H}$, Bunger C. Hydroxyapatite coating converts fibrous tissue to bone loaded implants. J Bone Joint Surg 1993; 75 - B: 270 - 278.
34. Salah Sakka, Paul Coulthard: Implant failure: Etiology and complications. Med Oral Patol Oral Cir Bucal. 2011 Jan 1; 16 (1): e42 - 4.

35. Sánchez-Gárces MA, Gay-Escoda C. Periimplantitis. Med Oral Patol Oral Cir Bucal. 2004; 9 Suppl: 69 - 74; 63 - 9.

36. Gröndahl K, Lekholm U. The predictive value of radiographic diagnosis of implant instability. Int $\mathbf{J}$ Oral Maxillofac Implants. 1997; 12: 59 - 64.

37. Shulman LB, Rogoff GS, Savitt ED, Kent RL Jr. Evaluation in reconstructive implantology. Dent Clin North Am. 1986; 30: 327- 49. 18. Sullivan DY, Sherwood RL, Collins TA, Krogh PH. The re- verse-torque test: a clinical report. Int J Oral Maxillofac Implants. 1996; 11: 179 - 85.

38. Tricio J, Laohapand P, Van Steenberghe D, Quirynen M, Naert I. Mechanical state assessment of the implant bone continuum: a better understanding of the Periotest method. Int J Oral Maxillofac Implants. 1995; 10: 43 - 9.

39. Yifat Manor, DMD, Saheer Oubaid, Ofer Mardinger, DMD, Gavriel Chaushu, DMD, MSc, $\S$ and Joseph Nissan, DMD: Characteristics of Early Versus Late Implant Failure: A Retrospective Study. 2009 American Association of Oral and Maxillofacial Surgeons J Oral Maxillofac Surg 67: 2649 - 2652, 2009.

40. Wagenberg, B. and Froum, S.J. (2006) A retrospective study of 1925 consecutively placed immediate implants from 1988 to 2004. The International Journal of Oral and Maxillofacial Implants 21: $71-80$. 